\title{
PENENTUAN POLA SEKUENSIAL DATA TRANSAKSI PENJUALAN MENGGUNAKAN ALGORITMA SEQUENTIAL PATTREN DISCOVERY USING EQUIVALENT CLASSES (SPADE)
}

\author{
Diki Andika Saputra ${ }^{1)}$, Eneng Tita Tosida ${ }^{2, \#), ~ F a j a r ~ D e l l i ~ W ' ~}{ }^{3)}$ \\ 1, 2 \& 3)Program Studi IImu Komputer, FMIPA, Universitas Pakuan, Bogor, Indonesia \\ \#) Corresponding Author: enengtitatosida@unpak.ic.id
}

Article history: received 10 March 2019; revised 25 May 2019; accepted 20 June 2019

\begin{abstract}
Abstrak
Data transaksi adalah data pelanggan atau pelanggan di lembaga komersial atau nonkomersial yang berisi id konsumen, waktu transaksi, dan item transaksi. Dari data transaksi seperti transaksi supermarket, pola berurutan dapat ditemukan untuk menentukan keterkaitan antara barang atau barang. Data jika diolah atau dianalisis lebih lanjut akan menghasilkan informasi atau pengetahuan yang penting dan berharga sebagai pendukung dalam pengambilan keputusan. Penelitian ini bertujuan untuk mengetahui pola konsumsi yang dimiliki oleh pelanggan dan memberikan informasi yang dapat digunakan dalam menentukan tata letak rak-rak toko baru. Algoritma SPADE adalah algoritma untuk menemukan pola sekuensial untuk memecah masalah utama menjadi sub-masalah yang dapat diselesaikan secara terpisah. Berdasarkan hasil yang diperoleh dapat disimpulkan bahwa penerapan algoritma SPADE memiliki nilai dukungan minimum tertinggi yang masih dapat membentuk urutan frekuensi maksimal yaitu $29 \%$. Nilai dukungan minimum tertinggi dari algoritma SPADE adalah 0,2\% dengan nilai kepercayaan minimum maksimum 81\% dan jumlah aturan yang terbentuk adalah 1.118 Aturan, tetapi kepercayaan diambil 60\% sehingga hanya ada 15 Aturan. Sedangkan algoritma Apriori memiliki nilai dukungan minimum tertinggi yang masih dapat membentuk urutan frekuensi maksimum adalah 25\%. Nilai dukungan minimum tertinggi dari algoritma apriori yang masih dapat membentuk aturan adalah 0,3\% dengan nilai maksimum kepercayaan minimum $88 \%$ dan jumlah aturan yang terbentuk sebanyak 494 Aturan, tetapi kepercayaan diambil 60\% ke atas sehingga ada hanya 29 Aturan.
\end{abstract}

Kata kunci: data mining, algoritma SPADE, algoritma apriori.

\begin{abstract}
Transaction data is customer or customer data at a commercial or non-commercial institution that contains the consumer id, transaction time, and transaction items. From transaction data such as supermarket transactions, sequential patterns can be found to determine the interrelationship between items or items. Data if further processed or analyzed will produce information or knowledge that is important and valuable as a support in decision making. This study aims to determine the consumption patterns owned by customers and provide information that can be used in determining the layout of new store shelves. The SPADE algorithm is an algorithm for finding sequential patterns to break down the main problem into sub-problems that can be solved separately. Based on the result obtained it can be concluded that the application of the SPADE algorithm has the highest minimum support value that can still form maximal frequent sequences is $29 \%$. The highest minimum support value of the SPADE algorithm is $0.2 \%$ with a maximum minimum confidence value of $81 \%$ and the number of rules formed is 1,118 Rule, but confidence is taken $60 \%$ up so that there are only 15 Rule. Whereas the Apriori algorithm has the highest minimum support value that can still form the maximum frequent sequences is $25 \%$. The highest minimum support value of the apriori algorithm which can still form a rule is $0.3 \%$ with a maximum value of $88 \%$ minimum confidence and the number of rules formed as many as 494 Rule, but confidence is taken $60 \%$ up so that there are only 29 Rule.
\end{abstract}

Keywords: data mining, algoritma SPADE, algoritma apriori. 


\section{Pendahuluan}

Pengolahan data secara cepat, efisien, dan efektif sangat diperlukan oleh manusia seiring dengan perkembangan zaman. Sedangkan disisi lain, data mentah yang memerlukan pemrosesan jumlahnya sangat banyak sehingga tidak memungkinkan lagi dilakukan pengolahan data secara manual. Salah satu data mining yang digunakan untuk mengatasi time-series database adalah sequential pattern mining [1]. Sequential pattern mining adalah pencarian frequent pattern dalam time-series database. Salah satu metode sequential pattern mining yaitu algoritma SPADE (Sequential Pattern Discovery using Equivalence classes = penemuan pola sequential menggunakan kelas yang setara) adalah sebuah algoritma baru untuk penemuan cepat pola sequential dalam sebuah database besar [2].

Data transaksi di PT Catur Mitra Sejati Sentosa (Mitra10) setiap hari dapat menghasilkan kumpulan data transaksi penjualan barang dalam ukuran besar, akan tetapi seringkali data tersebut hanya disimpan tanpa diolah lebih lanjut sehingga kumpulan data yang tersimpan tidak mempunyai nilai guna. Padahal jika diolah atau dianalisis lebih lanjut akan menghasilkan informasi atau pengetahuan yang penting dan berharga sebagai penunjang dalam pengambilan keputusan. Pengolahan dan analisis yang mendalam terhadap kumpulan data transaksi penjualan menjadi suatu pengetahuan yang berharga dapat dilakukan dengan menerapkan data mining. Data mining merupakan proses algoritma yang efisien untuk mendeteksi pola yang diinginkan terkandung dalam data yang diberikan. Demikian data langkah penambangan bertanggung jawab untuk menemukan pola

sesuai dengan tugas yang telah ditentukan [3]. Penerapan data mining dalam data transaksi penjualan barang di PT Catur Mitra Sejati Sentosa (Mitra10) diharapkan akan mampu menggali informasi mengenai pola perilaku konsumen dalam membeli barang yang dapat digunakan sebagai peningkatan mutu layanan di PT Catur Mitra Sejati Sentosa (Mitra10).

Data transaksi merupakan data konsumen atau pelanggan pada sebuah lembaga komersil maupun non-komersil yang berisi id konsumen, waktu transaksi, dan item transaksi. Dari data transaksi seperti halnya transaksi supermarket, dapat ditemukan pola sequential untuk mengetahui keterkaitan antar barang atau item [4].

Pada penelitian sebelumnya telah dibuat aplikasi mengenai pola sequential [4] yang berjudul "Pola Keterkaitan Nilai Mahasiswa IImu Komputer Ipb Alih Jenis Dengan Komponen Epbm Menggunakan Algoritma Spade" dengan tujuan untuk melihat keterkaitan antara beberapa komponen pemicu nilai akhir mata kuliah dengan berbagai kumpulan data. Algoritma Sequential Pattern Discovery using Equivalence Classes (SPADE) merupakan salah satu algoritma yang digunakan untuk melakukan penemuan cepat pola sequential. Mata kuliah menjadi masukan data untuk sid, angkatan untuk eid, dan pemicu nilai akhir mata kuliah seperti nilai mahasiswa, nilai EPBM, nilai diploma, dan status kerja sebagai items. Hasil dari penelitian ini menghasilkan kemunculan bersama maupun pola sequential dari pemicu nilai akhir mata kuliah mahasiswa. Dari hasil peneletian ini ditemukan bahwa angkatan 4 paling sering mengungguli angkatanangkatan sebelumnya dengan meraih nilai baik, dan ditemukan juga sebuah hubungan erat antara cara mengajar dosen yang baik dengan nilai akhir mata kuliah dari mahasiswa yang baik.

Penelitian terdahulu selanjutnya dilakukan oleh [5] yang berjudul "Association Rule Algorithm Sequential Pattern Discovery using Equivalent Classes (SPADE) to Analyze the Genesis Pattern of Landslides in Indonesia" dengan tujuan untuk mengetahui bagaimana pola hubungan antara urutan Peristiwa longsor dan untuk mengetahui bagaimana hubungan asosiatif pola gempa bumi. Berdasarkan dampaknya, hasil ini penelitian adalah pola hubungan asosiatif yang diperoleh dari data Banjir yang terjadi di Indonesia, yaitu dalam hal akan terjadi hujan lebat terjadi struktur tanah labil untuk mendukung nilai 0,37 , kepercayaan diri tingkat $41 \%$ dan kekuatan yang dibentuk memerintah adalah 1,02.

Adapun perbedaan antara penelitian terdahulu dengan penelitian ini adalah dalam penerapan algoritma, dalam penelitian terdahulu hanya menggunakan algoritma SPADE sedangkan dalam penelitian ini membandingkan hasil akurasi dua algoritma yaitu algoritma Apriori dan algoritma SPADE.

Penelitian ini bertujuan untuk membantu dalam menganalisis kecenderungan atau pola konsumsi yang dimiliki oleh pelanggan dan memberikan informasi yang dapat digunakan dalam menentukan tata letak rak toko yang baru. Mampu melihat keterkaitan antar barang yang dibeli oleh pembeli pada data transaksi penjualan.

Berdasarkan permasalahan di atas maka dilakukan penelitian mengenai penentuan pola sequential data transaksi penjualan. Berdasarkan data yang didapatkan dari administrasi PT 
Catur Mitra Sejati Sentosa (Mitra10). Sequential Pattern Discovery Using Equivalent Classes ( $S P A D E$ ) yang bekerja dengan menggunakan database vertikal dimana Dalam format data vertikal, database sequence menjadi berbentuk kumpulan urutan yang formatnya [itemset: (sequence_ID, event_ID)], dengan kata lain, untuk setiap itemset akan disimpan sequence identifier dan event identifier yang berkoresponden. Event Identifier berguna sebagai timestamp atau penanda waktu dari itemset tersebut. Sepasang (sequence_ID, event_ID) untuk setiap itemset membentuk ID_list dari itemset tersebut [6].

\section{Metode Penelitian}

Dalam penelitian ini metode yang digunakan adalah tahapan data mining atau disebut juga Knowledge Discovery and Data Mining (KKD), data mining adalah serangkaian proses untuk menggali nilai tambah dari suatu kumpulan data berupa pengetahuan yang selama ini tidak diketahui secara manual [15]. pertimbangan menggunakan model ini karena mempunyai tahapan yang cukup lengkap dan terstruktur [3]. Proses data mining yang dibagi menjadi beberapa tahap yang digambarkan pada Gambar 1.

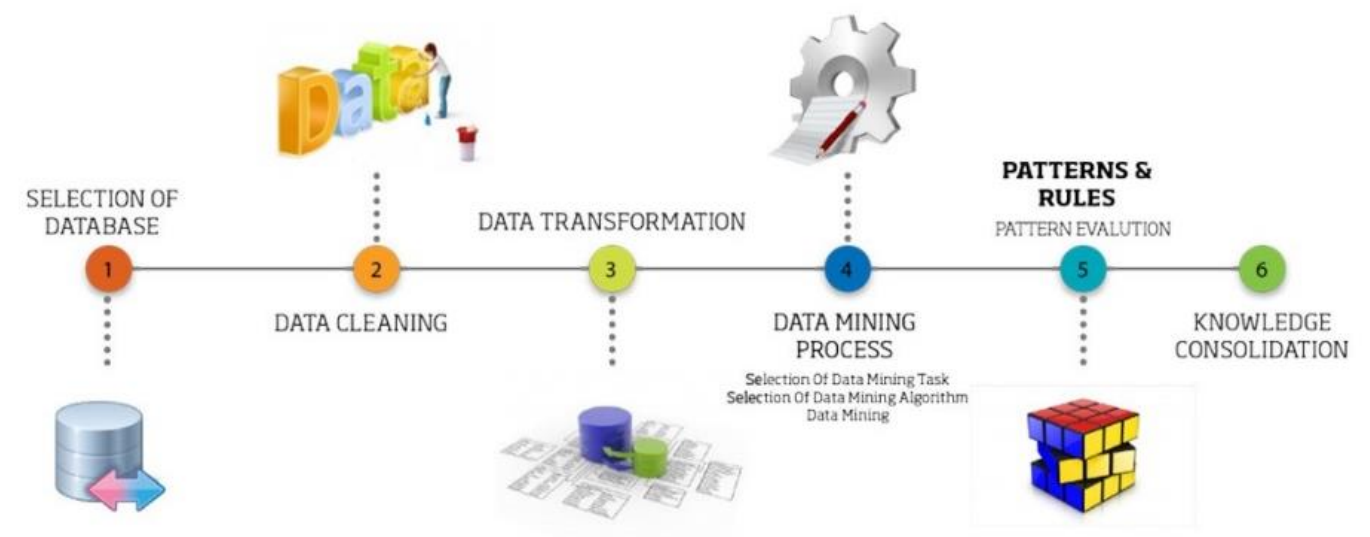

Gambar 1. Tahapan Data Mining

Tahap pembersihan data merupakan proses menghilangkan data yang tidak relevan. Pada umumnya data yang diperoleh, baik dari database memiliki isian-isian yang tidak sempurna seperti data yang hilang, data yang tidak valid atau juga hanya sekedar salah ketik. Data kosong diisi dengan nilai modus, menghapus data yang tidak konsisten [14]. Dari 44910 data setelah melalui tahap pembersihan data menjadi 5.813.

Tahap Seleksi data merupakan data yang ada pada database sering kali tidak semuanya dipakai, oleh karena itu hanya data yang sesuai untuk dianalisis yang akan diambil dari database. Sementara, transformasi data adalah proses dimana data diubah atau digabung ke dalam format yang sesuai untuk diproses dalam data mining. Beberapa metode data mining membutuhkan format data yang khusus sebelum bisa diaplikasikan [14].

Tahap transformasi data merupakan data diubah ke dalam bentuk yang sesuai sebagai masukan bagi algoritma SPADE. Konversi items ke dalam bentuk numerik. Items yang dibeli oleh pembeli diubah ke dalam bentuk numerik dengan memberikan kode yang dimulai dari 1 hingga 31. Paint dikodekan dengan 1, Ceramic Tile dikodekan dengan 2, demikian halnya dengan jenis barang lain. Data yang memiliki format Microsoft Excel (datahasil.xlsx) kemudian diubah ke dalam format text (datahasil.txt) sebagai masukan bagi algoritma SPADE.

Tahap data mining merupakan inti dari analisis data, proses menemukan wawasan, pola menarik, serta deskriptif, dimengerti, dan prediksi dari model data dari data berskala besar. Dengan melihat sifat dasar data yang dimodelkan sebagai matriks data, yang menekankan pandangan geometris dan aljabar, serta interpretasi probabilistik dari data. Interestingness measure yang dapat digunakan dalam data mining adalah [8]:

a. Support, adalah suatu ukuran yang menunjukkan seberapa besar tingkat dominasi suatu item atau itemset dari keseluruhan transaksi. 
b. Confidence, adalah suatu ukuran yang menunjukkan hubungan antar dua item secara conditional (berdasarkan suatu kondisi tertentu).

Mencari kombinasi item yang memenuhi syarat minimum dari nilai support dalam basis data. Nilai support sebuah item diperoleh dengan menggunakan rumus pada Persamaan 1

$$
\text { Support }(\mathrm{A} \rightarrow \mathrm{B})=\frac{\text { Jumlah transaksi itemset }(A \rightarrow B)}{\text { Total Transaksi }}
$$

Nilai Confidence diperoleh dengan rumus pada Persamaan 2

$$
\text { Confidence }(\mathrm{A} \rightarrow \mathrm{B})=\frac{\text { Jumlah Transaksi Itemset }(A \rightarrow B)}{\text { Jumlah Antacedent } A}
$$

c. Lift Ratio, adalah suatu ukuran untuk mengetahui kuat tidaknya sebuah rule. Lift ratio dapat dihitung dengan cara membandingkan nilai confidence dengan nilai benchmark confidence. Nilai dari benchmark confidence setiap rule didapatkan dari nilai jumlah transaksi consequent dibagi dengan jumlah transaksi [13]. Rumus untuk mencari nilai lift ratio dapat dilihat pada Persamaan 3.

$$
\text { Lift ratio }=\frac{\text { Confidence }(A, B)}{\text { Benchmark Confidence }(A, B)}
$$

Tahap evaluasi pola merupakan tahap dimana seluruh large sequence yang dihasilkan pada tahap data mining kemudian dievaluasi untuk mendapatkan pola sekuensial. Evaluasi dilakukan dengan mencari large sequence yang maksimal dari seluruh large sequence yang ada. Suatu sequence dikatakan maksimal jika sequence tersebut tidak termuat pada sequence lainnya. Pola sekuensial yang merupakan hasil evaluasi pola yang dilakukan terhadap seluruh large sequence yang terbentuk dari hasil percobaan pada tahap data mining. Dari seluruh pola sekuensial yang terbentuk, diambil pola sekuensial yang mempunyai minimum support tertinggi dari setiap jenis polanya. Hal ini berarti bahwa dari beberapa pola sekuensial yang sama, diambil satu pola sekuensial saja yang terjadi pada nilai minimum support tertinggi [9].

Tahap representasi pengetahuan dari pola sekuensial yang dihasilkan diperlukan agar pola yang ada mudah dimengerti dan diinterpretasikan. representasi pengetahuan adalah suatu deskripsi atau spesifikasi dari pengetahuan [10]. Representasi pengetahuan berarti pengetahuan dapat diekspresikan sebagai simbol yang dapat diterima menggunakan komputer yang selanjutnya dapat dideskripsikan ke dalam beberapa bentuk seperti struktur grafik, struktur pohon, dan kaidah pola kecocokan [11].

\section{Hasil dan Pembahasan}

Algoritma apriori merupakan salah satu algoritma klasik data mining. Algoritma apriori digunakan agar komputer dapat mempelajari aturan asosiasi, mencari pola hubungan antar satu atau lebih item dalam suatu dataset. Algoritma apriori banyak digunakan pada data transaksi atau biasa disebut market basket, misalnya sebuah swalayan memiliki market basket, dengan adanya algoritma apriori, pemilik swalayan dapat mengetahui pola pembelian seorang konsumen, jika seorang konsumen membeli item A, B, punya kemungkinan 50\% dia akan membeli item C, pola ini sangat signifikan dengan adanya data transaksi selama ini [5].

Algoritma SPADE merupakan algoritma untuk mencari pola sekuensial untuk menguraikan masalah utama menjadi submasalah yang dapat diselesaikan secara terpisah. Dalam format data vertikal, database sequence menjadi berbentuk kumpulan urutan yang formatnya [itemset :(sequence_id (sid), event_id (eid))] [1]. Dengan kata lain, untuk setiap itemset akan disimpan sequence identifier dan event identifier. Diagram alur dari Algoritma SPADE dan Apriori dapat dilihat pada Gambar 2. 

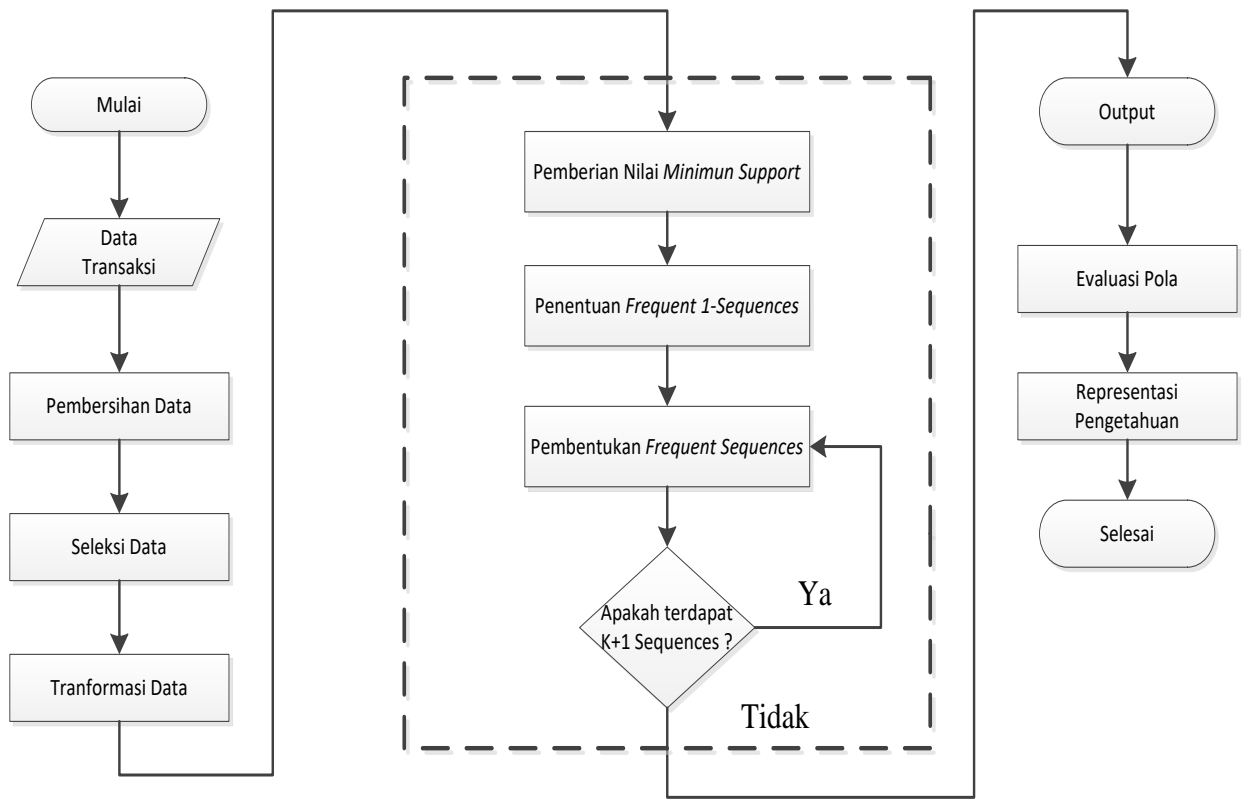

Gambar 2. Diagram Alur

Implementasi algoritma SPADE dan Apriori menggunakan bahasa pemrograman $\mathrm{R}$, sehingga dapat melakukan association rule mining dengan mudah dan cepat. Terdapat beberapa library untuk melakukan association rule mining di R, seperti contohnya library, library arules, library arulessequence, dan library aruleviz. Library yang pertama digunakan untuk menyediakan fungsi umum dan metode untuk menyingkat label item panjang dalam transaksi, asosiasi (aturan dan item) dan daftar ID transaksi. Kemudian library yang kedua digunakan untuk arules untuk menangani dan menambang urutan item yang sering dibeli pada data transaksi penjualan, menggabungkan sekumpulan sekuens (waktunya) atau aturan sekuens menjadi satu objek.

Tahap selanjutnya adalah implementasi interface yang sudah dirancang ke dalam bentuk sistem, untuk selanjutnya dilakukan pengujian terhadap aplikasi. Hasil dari User Interface aplikasi dapat dilihat pada Tabel 1.

Tabel 1. Hasil User Interface.

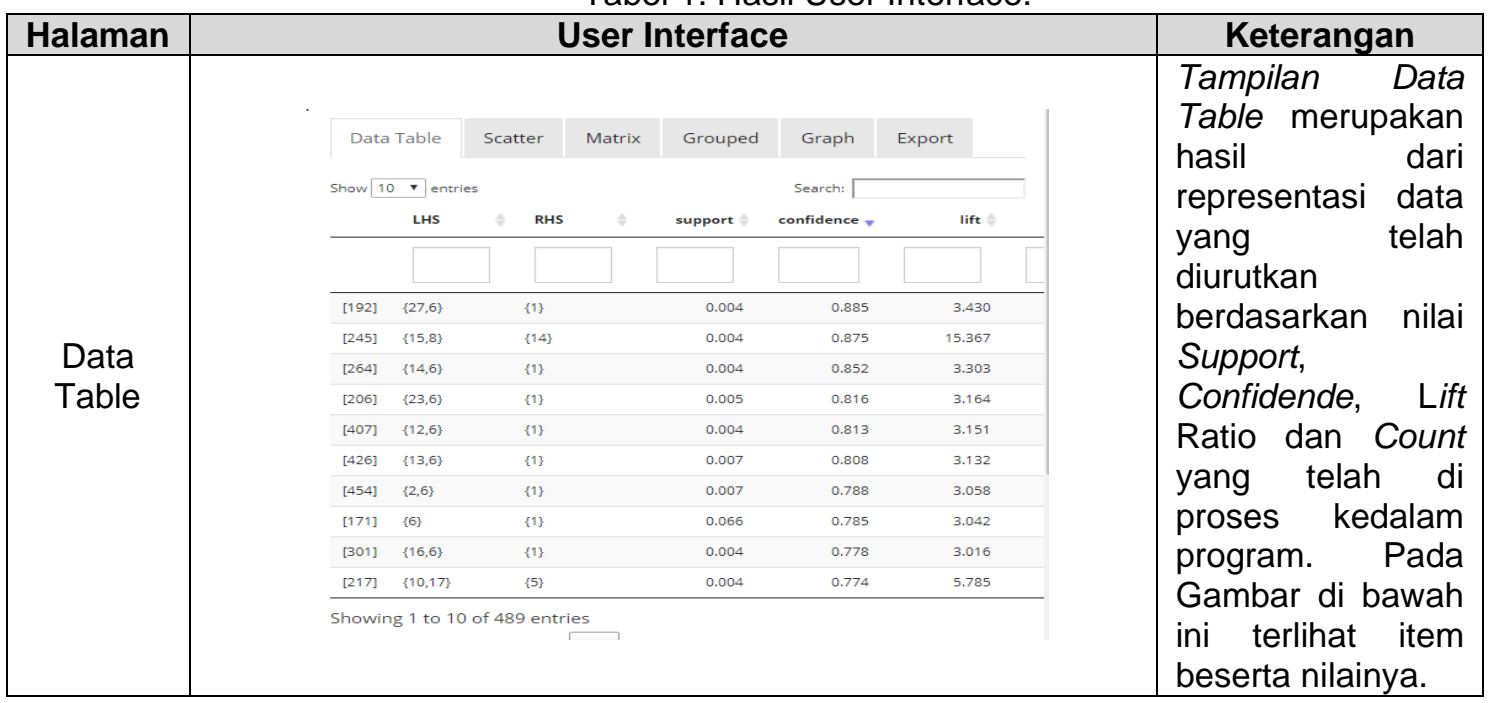




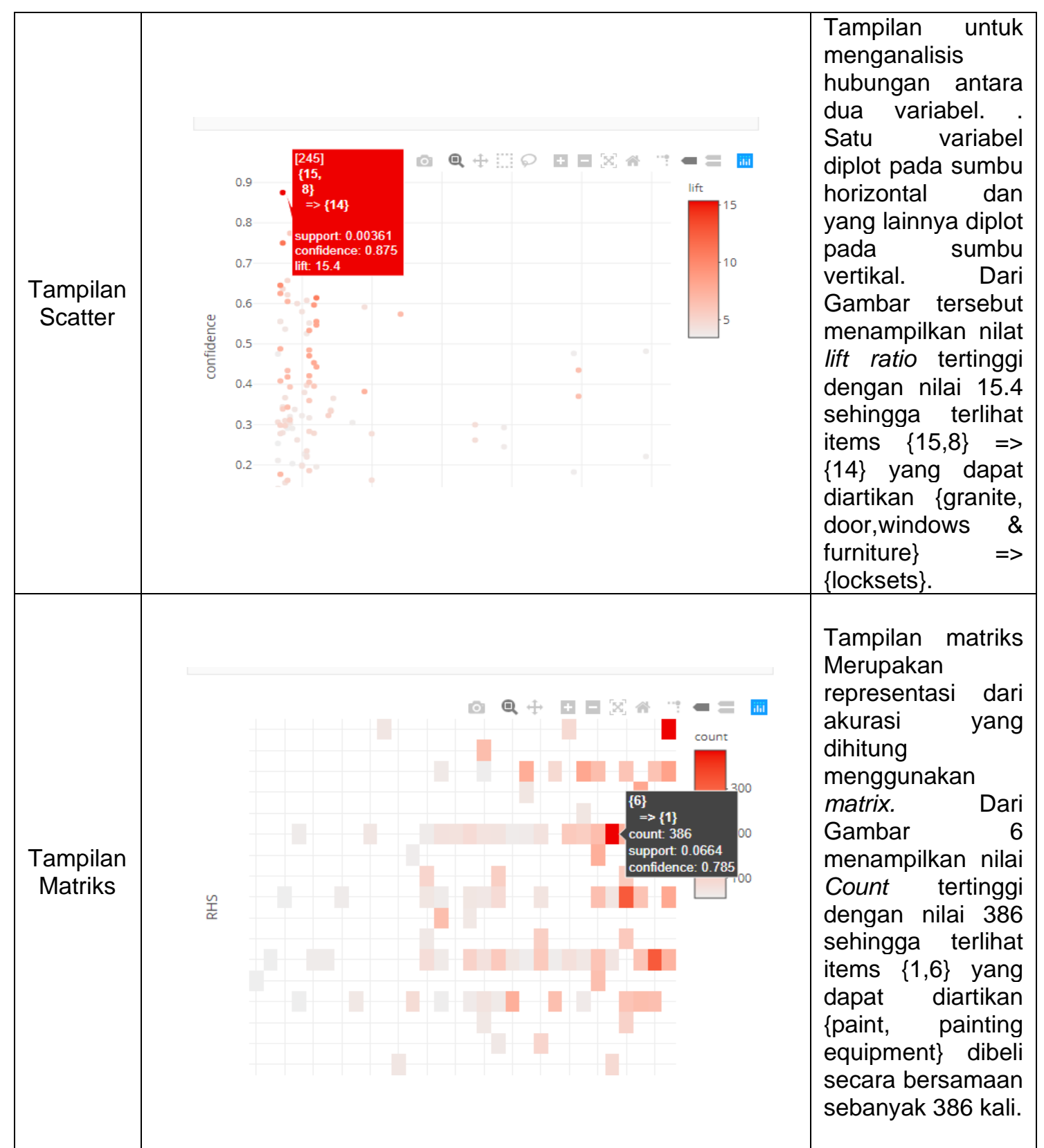


KOMPUTASI (Jurnal IImiah IImu Komputer dan Matematika)

Vol. 16, No. 2, Juli 2019, Hal. $273-282$

P-ISSN: 1693-7554, E-ISSN: 2654-3990

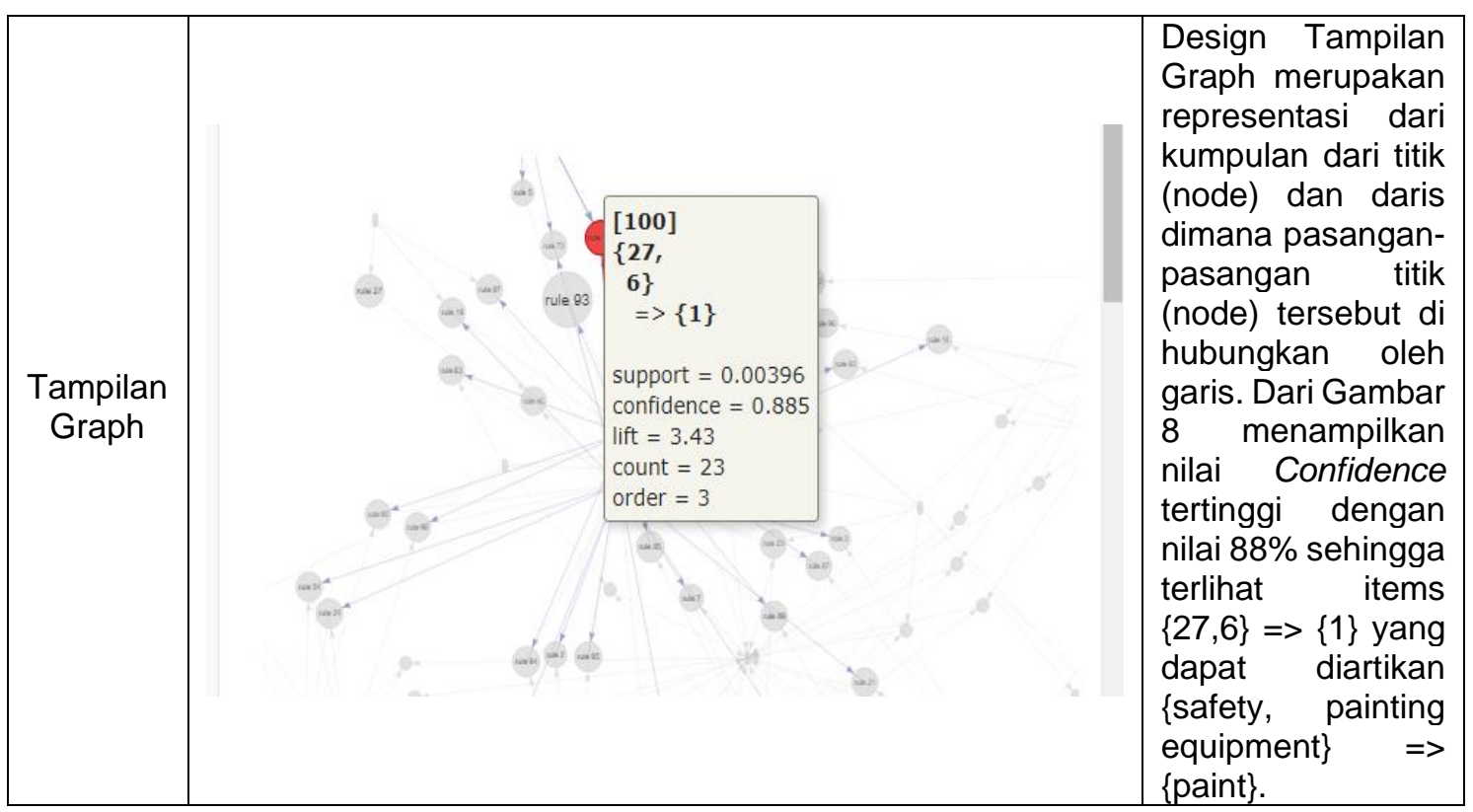

Penentuan pola sekuiensial pertama kali diperkenalkan oleh Agrawal dan Srikant pada tahun 1994. Pola sekuensial adalah pola yang menggambarkan urutan waktu dari peristiwa yang sering terjadi. Diberikan satu set sequence, dimana setiap sequence terdiri dari satu set item, dan diberikan sebuah batasan minimum support yang ditentukan oleh pengguna, sequential pattern mining adalah menemukan seluruh sub-sequence dimana frekuensi kemunculannya tidak lebih kecil dari minimum support [6].

Salah satu algoritma yang dapat digunakan untuk mengetahui pola sekuensial dari suatu data transaksi yaitu Sequential Pattern Discovery using Equivalence classes (SPADE). Algoritma $S P A D E$ merupakan algoritma berbasis candidate generation and test dan merupakan penyempurnaan dari algoritma penentuan pola sekuensial terdahulu yakni Apriori [6].

Dengan mengadopsi fungsi-fungsi pada algoritma SPADE, akan dilihat kecenderungan pembelian barang oleh customer dalam kurun waktu tertentu. Kejadian seperti ini sebenarnya terekam dalam database, hanya saja belum tergali informasi tentang itu. Dengan mencari polapola dari database menggunakan algoritma $S P A D E$, akan terlihat keterkaitan jenis barang yang dibeli oleh pembeli pada waktu tertentu [7].

Berdasarkan percobaan yang dilakukan terhadap data transaksi penjualan PT Catur mitra sejati Sentosa. Nilai minimum support tertinggi hingga masih terbentuk adalah $29 \%$ dan $25 \%$ dengan jumlah frequent sequnces sebanyak satu. Hasil lengkap pembentukan Nilai Minimum yang terbentuk dari data transaksi pembelian PT Catur mitra sejati sentosa dapat dilihat pada Gambar 3. 

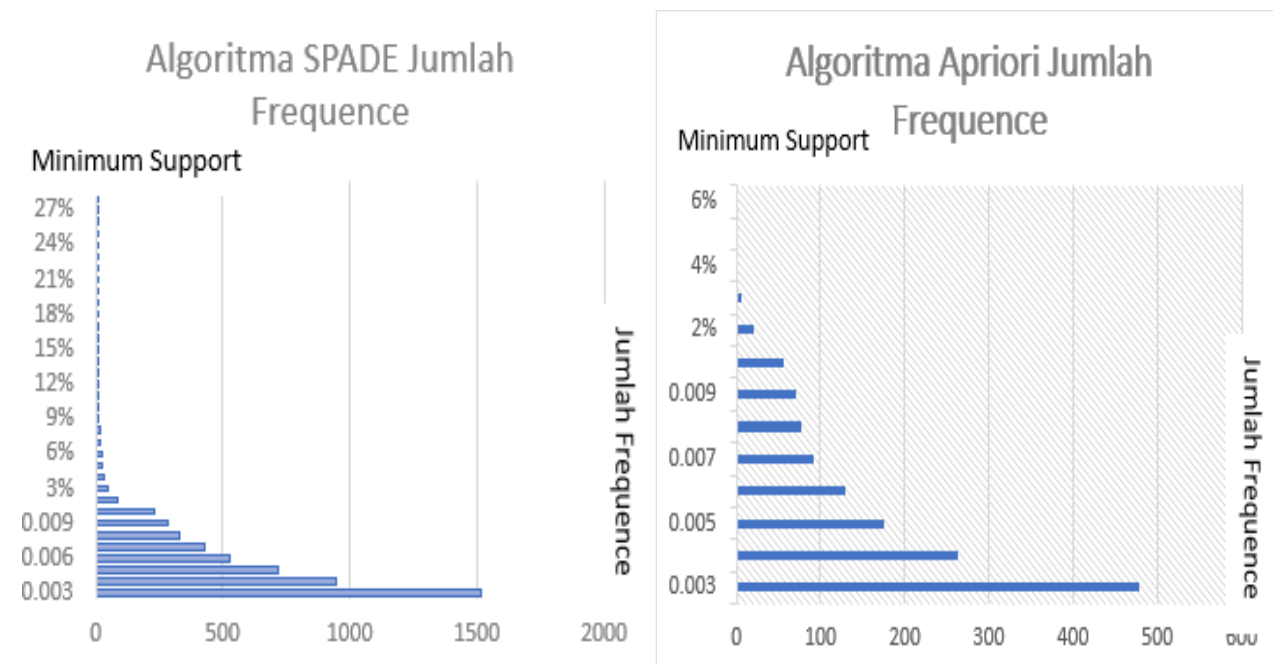

Gambar 3. Pembentukan frequent sequences

Nilai minimum support tertinggi dari algortima SPADE membentuk rule adalah $0.2 \%$ dengan nilai maksimal minimum confidence sebesar $81 \%$ dan jumlah rule yang terbentuk sebanyak 1.118 Rule. Setelah di dapat support dan confidence untuk masing-masing kandidat, dimana confidence-nya di ambil $60 \%$ ke atas sehingga terdapat 15 Rule, dimana pada nilai confidence tertinggi terdapat rule <\{granite tile\},\{ceramic tile\},\{ceramic tile,granite tile $\}=><$ ceramic tile $\}>$ yang memiliki confidence sebesar $81 \%$ mengandung arti bahwa apabila pembeli PT Catur mitra sejati sentosa membeli \{granite tile\},\{ceramic tile\},\{ceramic tile,granite tile $\}>$ lalu transaksi selanjutnya akan membeli $<\{$ ceramic tile $\}>$. Nilai tersebut terdapat pada Tabel 2.

Tabel 2. Nilai Confidence Algoritma Spade

\begin{tabular}{|c|c|c|c|c|}
\hline No & Rule & Support & Confidence & Lift \\
\hline 1 & $\langle\{$ Granite Tile $\},\{$ Ceramic Tile $\},\{$ Ceramic Tile,Granite Tile $\}\rangle=\rangle\langle\{$ Ceramic Tile $\}\rangle$ & 0.002382844 & 0.8181818 & 3.5892 \\
\hline 2 & $\langle\{$ Cement $\},\{$ Paint,Hand Tools $\}>=><\{$ Paint $\}>$ & 0.002118083 & 0.8 & 2.732 \\
\hline 3 & $\langle\{$ Sanitary Wares $\},\{$ Painting Equipment $\}\rangle=\rangle\langle\{$ Ceramic Tile $\}\rangle$ & 0.002118083 & 0.7272727 & 3.1904 \\
\hline 4 & $\langle\{$ Sanitary Wares $\},\{$ Paint,Painting Equipment $\}\rangle=\rangle\langle\{$ Ceramic Tile $\}\rangle$ & 0.002118083 & 0.7272727 & 3.1904 \\
\hline 5 & $\langle\{$ Sanitary Fittings,Door Window \& Furniture $\},\{$ Ceramic Tile $\}\rangle=>\langle\{$ Ceramic Tile $\}\rangle$ & 0.002118083 & 0.7272727 & 3.1904 \\
\hline 6 & $\langle\{$ Paint,Lighting $\},\{$ Paint,Painting Equipment $\}>=>\langle\{$ Paint $\}\rangle$ & 0.002118083 & 0.7272727 & 2.4836 \\
\hline 7 & $\langle\{$ PaintPainting Equipment $\},\{$ Granite Tile $\}>=>\langle\{$ Ceramic Tile $\}>$ & 0.002118083 & 0.6666667 & 2.9245 \\
\hline 8 & $\langle\{$ Electrical $\},\{$ Sanitary Fittings $\},\{$ Electrical $\}\rangle=>\langle\{$ Paint $\}\rangle$ & 0.002118083 & 0.6666667 & 2.2767 \\
\hline 9 & $\langle\{$ Ceramic Tile,Doors,Granite Tile $\}==\rangle\langle\{$ Ceramic Tile $\}\rangle$ & 0.002118083 & 0.6153846 & 2.6995 \\
\hline 10 & $\langle\{$ Ceramic Tile,Granite Tile $\},\{$ Ceramic Tile $\},\{$ Ceramic Tile $\}\rangle=\rangle\langle\{$ Ceramic Tile $\}\rangle$ & 0.002118083 & 0.6153846 & 2.6995 \\
\hline 11 & $\langle\{$ Lighting $\},\{$ Cement $\},\{$ Ceramic Tile $\}>=>\langle\{$ Cement $\}\rangle$ & 0.002118083 & 0.6153846 & 5.6007 \\
\hline 12 & $\langle\{$ Electrical $\},\{$ Door Window \& Furniture,Locksets $\}>=>\langle\{$ Paint $\}\rangle$ & 0.002118083 & 0.6153846 & 2.1015 \\
\hline 13 & $\langle\{$ Paint,Lighting $\},\{$ Painting Equipment $\}\rangle=>\langle\{$ Paint $\}\rangle$ & 0.002118083 & 0.6153846 & 2.1015 \\
\hline 14 & $\langle\{$ Paint,Lighting $\},\{$ Cement $\}>=>\langle\{$ Paint $\}>$ & 0.002118083 & 0.6153846 & 2.1015 \\
\hline 15 & $\langle\{$ Sanitary Fittings, Painting Equipment $\},\{$ Paint $\}>=>\langle\{$ Paint $\}\rangle$ & 0.002118083 & 0.6153846 & 2.1015 \\
\hline
\end{tabular}

Sedangkan Nilai minimum support tertinggi dari algortima Apriori yang masih bisa membentuk rule adalah $0.3 \%$ dengan nilai maksimal minimum confidence sebesar $88 \%$ dan jumlah rule yang terbentuk sebanyak 494 Rule. Setelah di dapat support dan confidence untuk masing-masing kandidat, dimana confidence-nya di ambil $60 \%$ ke atas sehingga hanya terdapat 29 Rule, dimana pada nilai confidence tertinggi terdapat rule (safety, painting equipment) ==> (paint) yang mengandung arti bahwa apabila pembeli PT Catur mitra sejati sentosa membeli safety dan painting equipment maka peluang electrical juga dibeli oleh pembeli tersebut adalah sebesar $88 \%$, Nilai tersebut terdapat pada Tabel 3 
KOMPUTASI (Jurnal IImiah IImu Komputer dan Matematika)

Vol. 16, No. 2, Juli 2019, Hal. $273-282$

P-ISSN: 1693-7554, E-ISSN: 2654-3990

https://journal.unpak.ac.id/index.php/komputasi

Tabel 3. Nilai Confidence Algoritma Apriori

\begin{tabular}{|c|c|c|c|c|c|}
\hline No & LHS & RHS & Support & Confidence & Lift \\
\hline 1 & \{Safety,Painting Equipment\} & \{Paint $\}$ & 0.004 & 0.885 & 3.43 \\
\hline 2 & $\{$ Granite Tile,Door Window \& Furniture $\}$ & $\{$ Locksets\} & 0.004 & 0.875 & 15.367 \\
\hline 3 & $\{$ Locksets,Painting Equipment $\}$ & $\{$ Paint $\}$ & 0.004 & 0.852 & 3.303 \\
\hline 4 & \{Adhesive,Painting Equipment\} & $\{$ Paint $\}$ & 0.005 & 0.816 & 3.164 \\
\hline ........... & \{Cleaning Supplies,Painting Equipment\} & $\{$ Paint $\}$ & 0.004 & 0.813 & 3.151 \\
\hline ............ & $\{$ Granite Tile,Sanitary Wares $\}$ & $\{$ Ceramic Tile $\}$ & 0.003 & 0.621 & 2.926 \\
\hline 26 & $\{$ Ceramic Tile,Door Window \& Furniture & $\{$ Locksets $\}$ & 0.006 & 0.614 & 10.784 \\
\hline 27 & $\{$ Sanitary Wares,Lighting\} & \{Sanitary Fittings\} & 0.005 & 0.608 & 4.542 \\
\hline 28 & $\{$ Paint,Safety $\}$ & $\{$ Painting Equipment\} & 0.004 & 0.605 & 7.151 \\
\hline 29 & \{Pipe \& Fittings,Lighting\} & $\{$ Sanitary Fittings $\}$ & 0.005 & 0.6 & 4.483 \\
\hline
\end{tabular}

Perbandingan antara tatak letak barang PT catur mitra sejati sentosa dengan tata letak rekomendasi dari hasil penelitian.

a. Tata letak aktual PT catur mitra sejati sentosa

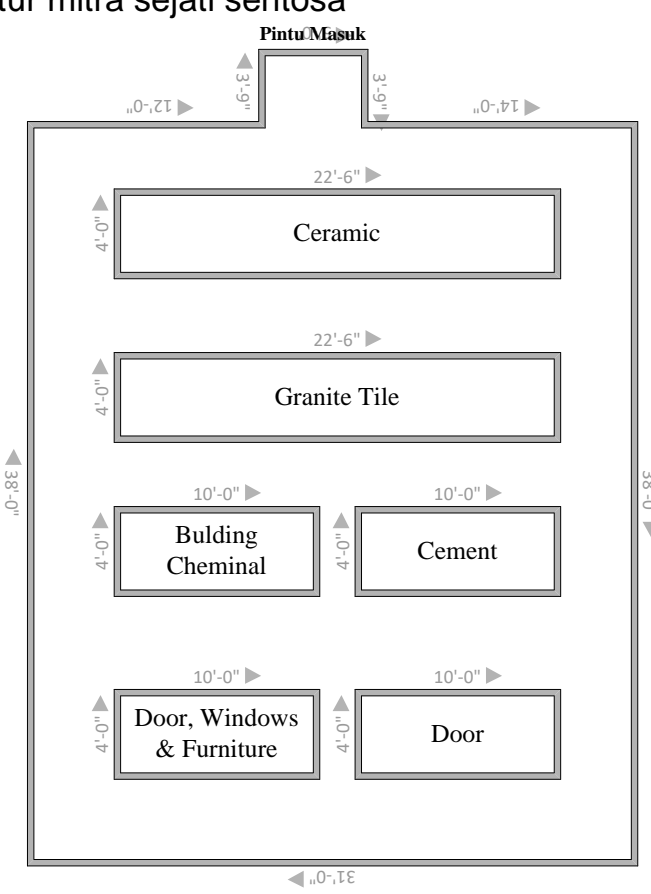

Gambar 4. Tata Letak Aktual Lantai 1

Item yang terdapat pada Gambar 4 meliputi ceramic, door, door windows \& furniture, granite tile, cement, dan bulding cheminal. 


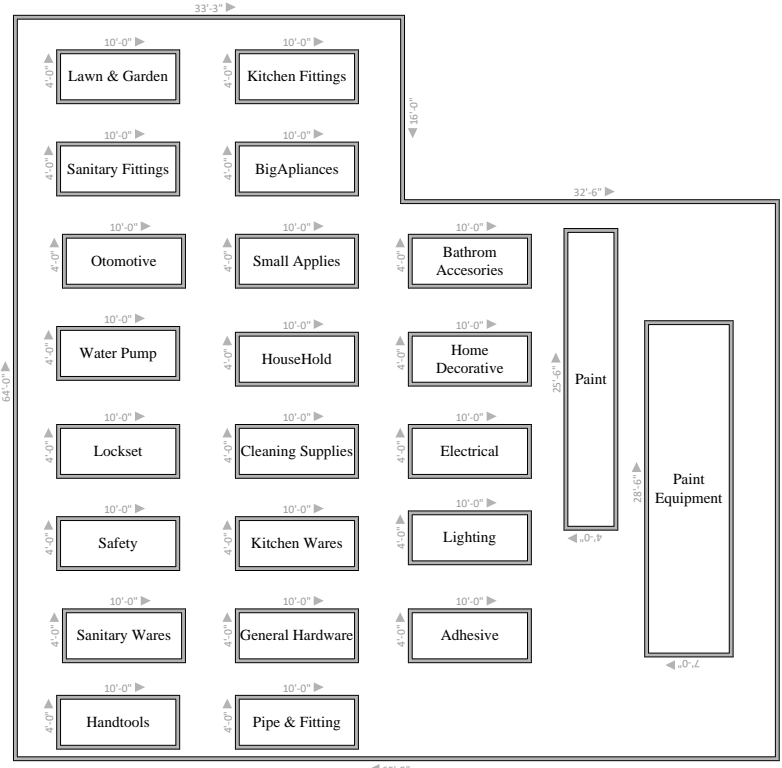

Gambar 5. Tata Letak Aktual Lantai 2

Item yang terdapat pada Gambar 5 meliputi household, lighting, locksets, kitchen wares, adhesive, door, big appliances, kitchen fittings, pipe\& fitting, lawn \& garden, bathroom accessories, small appliances, general hardware, sanitary fittings, automotive, water pump, handtools, home decorative, cleaning supplies, electrical, safety, sanitary wares, paint, dan painting equipment

b. Tata letak rekomendasi

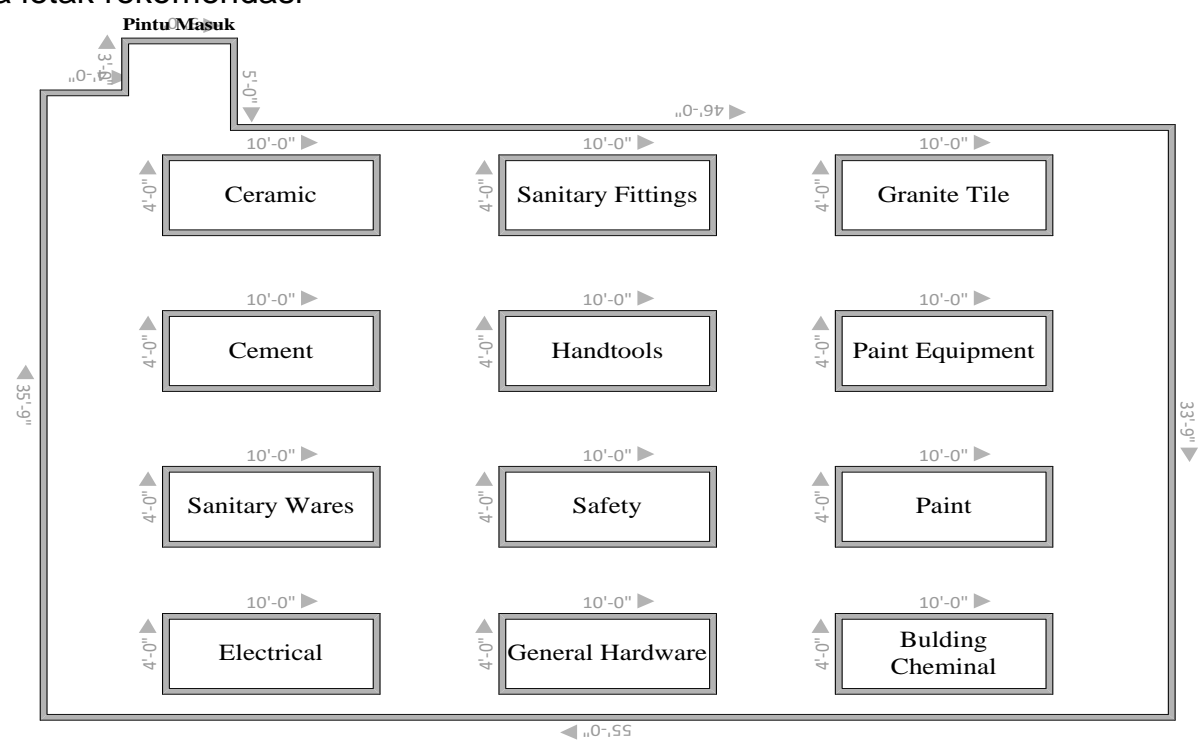

Gambar 6. Tata Letak Rekomendasi Lantai 1

Berdasarkan hasil penelitian, terdapat beberapa saran bagi pengelola PT Catur mitra sejati sentosa untuk penempatan tata letak barang. Rekomendasi tata letak penempatan barang dapat dilihat pada Gambar 5 dan Gambar 6.

Item yang terdapat pada Gambar 7 meliputi ceramic, sanitary fitting, granite tile, cement, handtools, paint equipment, sanitary wares, safety, paint, electrical, general hardware dan bulding cheminal. 


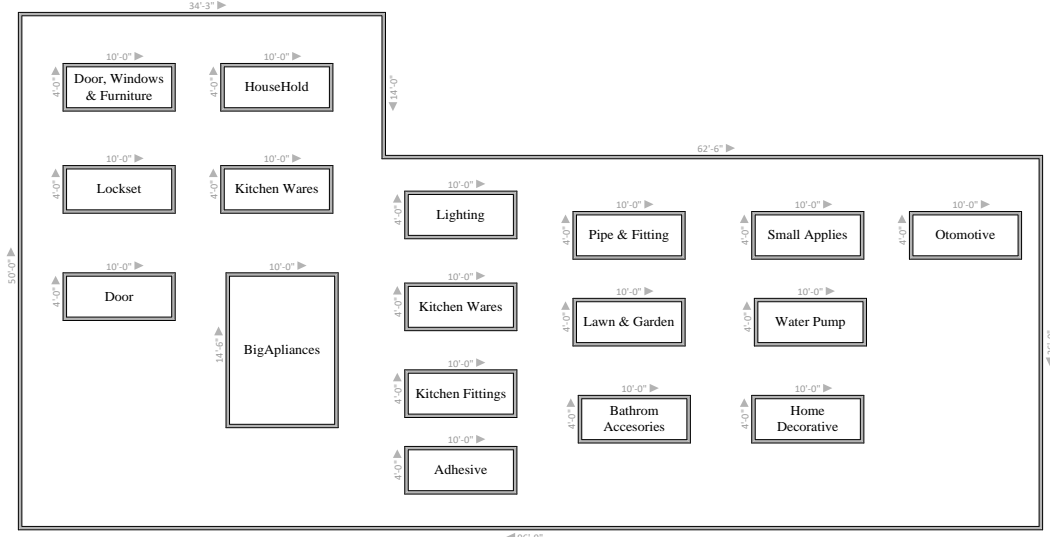

Gambar 7. Tata Letak Rekomendasi Lantai 2

Sedangkan Item yang terdapat pada Lantai 2 meliputi door window \& furniture, houdehold, lighting, locksets, kitchen wares, adhesive, door, big appliances, kitchen fittings, pipe \& fitting, lawn \& garden, bathroom accessories, samall applies, dan water pump.

\section{Kesimpulan}

Data transaksi di PT Catur Mitra Sejati Sentosa (Mitra10) setiap hari dapat menghasilkan kumpulan data transaksi penjualan barang dalam ukuran besar. Akan tetapi seringkali data tersebut hanya disimpan tanpa diolah lebih lanjut sehingga kumpulan data yang tersimpan tidak mempunyai nilai guna. Padahal jika diolah atau dianalisis lebih lanjut akan menghasilkan informasi atau pengetahuan yang penting dan berharga sebagai penunjang dalam pengambilan keputusan. Data yang digunakan dalam penelitian ini adalah transaksi penjualan PT catur mitra sejati Sentosa yang berjumlah 5.813 data dengan 4 atribut kategorik dalam format .xlsx yang kemudian diubah ke dalam format .txt sebagai masukan bagi algoritma SPADE.

Berdasarkan data yang diperoleh dapat disimpulkan bahwa penerapan algoritma SPADE memiliki nilai minimum support tertinggi yang masih bisa membentuk maximal frequent sequences adalah $29 \%$. Nilai minimum support tertinggi dari algortima SPADE adalah $0.2 \%$ dengan nilai maksimal minimum confidence sebesar $81 \%$ dan jumlah rule yang terbentuk sebanyak 1.118 Rule, namun confidence di ambil $60 \%$ ke atas sehingga hanya terdapat 15 Rule.

Sedangkan algortima Apriori memiliki nilai minimum support tertinggi yang masih bisa membentuk maximal frequent sequences adalah $25 \%$. Nilai minimum support tertinggi dari algortima Apriori yang masih bisa membentuk rule adalah $0.3 \%$ dengan nilai maksimal minimum confidence sebesar $88 \%$ dan jumlah rule yang terbentuk sebanyak 494 Rule, namun confidence di ambil $60 \%$ ke atas sehingga hanya terdapat 29 Rule. Untuk meningkatkan penjualan, pihak pengelola PT catur mitra sejati sentosa sebaiknya menempatkan barang yang saling berhubungan secara berdekatan sehingga pembeli dapat dengan mudah menjangkau kedua barang tersebut.

\section{Referensi}

[1] M. J. Zaki. 2001. SPADE: An efficient algorithm for mining frequent sequences. Machine Learning Journal, 42(1/2):31-60, Special issue on Unsupervised Learning (D. Fisher, editor).

[2] Juliastio. J. \& Gunawan. 2015. Sequential pattern mining dengan spade untuk prediksi pembelian spare part dan aksesoris komputer pada kedatangan kembali konsumen, Bogor

[3] Han J., M. Kamber. \& J. Pei. 2011. Data Mining Concepts and Techniques. $3^{\text {rd }}$ Edition. USA. Morgan Kaufmann Publishers. 
[4] Agung M., T. 2015. Penerapan data mining pada data transaksi penjualan untuk mengatur penempatan barang menggunakan algoritma apriori, Semarang: Program Studi Teknik Informatika - S1, Fakultas Ilmu Komputer, Universitas Dian Nuswantoro Semarang.

[5] Rodiyansyah, S., F \& A. Mardiana. 2017. Purwarupa Perangkat Lunak Pendeteksi Pola Jawaban Siswa Menggunakan Algoritma Apriori, Majalengka: Program Studi Teknik Informatika, Fakultas Teknik, Majalengka.

[6] Rusdy, Z., A. 2014. Pola Keterkaitan Nilai Mahasiswa IImu Komputer IPB Alih Jenis Dengan Komponen Epbm Menggunakan Algoritma Spade, Bogor: Fakultas Matematika Dan IImu Pengetahuan Alam Institut Pertanian Bogor

[7] Sijabat, R. 2011. Penentuan Pola Sekuensial Data Transaksi Pembelian Menggunakan Algoritma SPADE, Bogor: Fakultas Matematika dan IImu Pengetahuan Alam, Institut Pertanian Bogor.

[8] Yanto, R., R. Khoiriah. 2016. Implementasi Data Mining dengan Metode Algoritma Apriori dalam Menentukan Pola Pembelian Obat, Sumatera Selatan: Sistem Informasi STMIK Bina Nusantara Jaya Lubuklingau.

Agung, H. 2016. Penentuan Pola Sekuensial Pada Data Transaksi Perpustakaan IPB

[9] Menggunakan Algoritma Graph Search Techniques, Bogor: Departemen IImu Komputer Fakultas Matematika Dan IImu Pengetahuan Alam Institut Pertanian Bogor

[10] Hua Wang. 2011. Research on the Model of Knowledge Representation Ontology Based on Framework in Intelligent Learning System, IEEE International Conference on Electrical and Control Engineering (ICECE) pp. 6757-6760.

[11] YanLei., W. Xinying, \& D. Junlei, "A Power Grid Knowledge Representation Using Agent Based Knowledge Representation in Pervasive Computing", The 2nd IEEE International Conference on Information Management and Engineering (ICIME), Vol. 2, pp. 297-300.

[12] Ardiansyah, R. 2013. Sequential Pattern Mining pada Data Transaksi Penjualan Menggunakan Algoritma Sequential Pattern Discovery Using Equivalent Classes (SPADE).

Malang: Program Teknologi Informasi dan Ilmu Komputer Universitas Brawijaya.

[13] Santoso, B. 2007. Data Mining: Teknik Pemanfaatan Data untuk Keperluan Bisnis. Yogyakarta: Graha IImu.

[14] Rusdy, Z., A. 2014. Pola Keterkaitan Nilai Mahasiswa Ilmu Komputer IPB Alih Jenis Dengan Komponen Epbm Menggunakan Algoritme Spade, Bogor: Fakultas Matematika Dan IImu Pengetahuan Alam Institut Pertanian Bogor.

[15] Pramudiono, I. 2007. Pengantar Data Mining: Menambang Permata Pengetahuan di Gunung Data. 